\title{
Note
}

\section{Silver-white Variants of the Eastern Red-backed Salamander, Plethodon cinereus, from Eastern Canada}

\author{
MARTIN OuELlet ${ }^{1,3}$ and JeAn-DAVID MoORE ${ }^{2}$ \\ ${ }^{1}$ Amphibia-Nature, 8747 rue Lucien-Plante, Montréal, Québec H2M 2M7 Canada \\ ${ }^{2}$ Ministère des Forêts, de la Faune et des Parcs, Direction de la recherche forestière, 2700 rue Einstein, Québec, Québec G1P 3 W8 \\ Canada \\ ${ }^{3}$ Corresponding author: mouellet@amphibia-nature.org
}

Ouellet, Martin, and Jean-David Moore. 2016. Silver-white variants of the Eastern Red-backed Salamander, Plethodon cinereus, from eastern Canada. Canadian Field-Naturalist 130(2): 133-136.

The Eastern Red-backed Salamander (Plethodon cinereus) is well known for its colour polymorphism, which includes 8 colour phenotypes: the red-backed (striped), lead-backed (unstriped), and erythristic morphs, as well as the iridistic, albino, leucistic, amelanistic, and melanistic anomalies. Among these, the prevalence and geographic distribution of rare morphs have received little attention. In this article, we report 2 occurrences of silver-white variants of the red-backed morph of $P$. cinereus from Québec, Canada. To our knowledge, these variations in stripe colour on the red-backed phenotype represent the first 2 documented mentions for eastern Canada.

Key Words: Coloration; colour morph; dorsal stripe; silver-white variant; red-backed morph; Eastern Red-backed Salamander; Plethodon cinereus; Québec; Canada

\section{Introduction}

The Eastern Red-backed Salamander, Plethodon cinereus, has a broad geographic distribution in northeastern North America (Petranka 1998; Moore and Ouellet 2015). Like other terrestrial plethodontid salamanders, it plays an important role in forest ecosystems (Hickerson et al. 2012; Walton 2013; Semlitsch et al. 2014). This salamander's striking colour polymorphism has long attracted the attention of herpetologists and naturalists. Eight colour phenotypes are known and have been recently reviewed (Moore et al. 2012; Moore and Ouellet 2014). The red-backed (striped) and lead-backed (unstriped) morphs occur in most populations of $P$. cinereus, but in very different proportions (Moore and Ouellet 2015). The erythristic morph is also sporadically observed, but the iridistic, albino, leucistic, amelanistic, and melanistic anomalies are much rarer (Moore and Ouellet 2014).

In the red-backed morph of $P$. cinereus, the mid-dorsal stripe is generally red-orange, with gray-black borders that become mottled with white along the lower half of the body sides. Mid-dorsal stripe colours other than redorange, such as shades of brown, gray, pink, white, and yellow, have also been reported (Bishop 1941; Test and Bingham 1948; Schueler 1975; Moore and Ouellet 2014). Surprisingly, little photographic evidence of these colour variations exists in the published literature. The dorsal stripe usually extends from the head to the tail; some individuals also show variations, such as disconnected stripe sections along the body or tail.

Silver-white variants of the red-backed morph of $P$. cinereus have recently been observed in the states of Ohio (Figure 18-1-C in Anthony and Pfingsten 2013;
Figure 5 in Moore and Ouellet 2014), Pennsylvania (Figure 2 in Neff et al. 2015; C. D. Anthony, unpublished data), and Virginia (Project Noah, unpublished data; Virginia Herpetological Society, unpublished data). "White-striped morphs" of $P$. cinereus have also been reported in Massachusetts and New York (Schueler 1975; Haines-Eitzen 2015). Furthermore, one account of a "silver-backed phase" and another of a "ghostbacked phase" with a white dorsal stripe have been described for the closely related Southern Red-backed Salamander (Plethodon serratus) in Missouri (Drake and O'Donnell 2014). The dorsal stripes in these rare occurrences vary from gray to silver-white or white. In this article, we document 2 new occurrences of silverwhite variants of the red-backed morph of $P$. cinereus in Québec, Canada.

\section{Methods}

The 2 observations presented here were made by the authors during their multiple herpetological surveys, some of which specifically targeted $P$. cinereus (Moore and Ouellet 2015). In these surveys, unusual colorations were documented using various means, including digital photography vouchers. We measured snout-vent length (snout to middle of vent on the first specimen, and snout to posterior margin of vent on the second specimen) and total length (snout to tip of the tail) in the field with electronic calipers. Both specimens were immediately released on-site following documentation.

\section{Results}

The first silver-white specimen of $P$. cinereus was a subadult observed in May 2014, under a rock in the re-

A contribution towards the cost of this publication has been provided by the Thomas Manning Memorial Fund of the Ottawa Field-Naturalist's Club. 
gional county municipality of Lévis, Québec $\left(46^{\circ} 44^{\prime} \mathrm{N}\right.$, $71^{\circ} 11^{\prime} \mathrm{W}$; datum WGS84). This area is located on the south shore of the St. Lawrence River, across from Québec City. The habitat consisted of a deciduous forested outcrop at an elevation of $90 \mathrm{~m}$. The salamander's mid-dorsal stripe was silver-white (Figure 1), without visible xanthophores (yellow and red pigment cells or erythrophores), but with somewhat iridescent golden flecks. Its dorsolateral body was gray-black, while its ventral body was coarsely mottled with black and white, resulting in the distinctive salt-and-pepper appearance of the species. The pigmentation of both its irises was also standard. The specimen's length was $30.7 \mathrm{~mm}$ snout to vent and $54.7 \mathrm{~mm}$ in total. On this particular site, we encountered 49 other individuals of $P$. cinereus, all of the standard red-backed morph.

The second specimen, an adult, was observed in July 2014 under woody debris in the metropolitan area of Québec City, Québec $\left(46^{\circ} 45^{\prime} \mathrm{N}, 71^{\circ} 19^{\prime} \mathrm{W}\right.$; datum WGS84). This area is on the north shore of the St. Lawrence River, almost facing the first location (Lévis). The site was in a forested park, at an elevation of $80 \mathrm{~m}$. The habitat consisted of mostly uneven-aged Sugar Maples (Acer saccharum). As on the first specimen, the mid-dorsal stripe was silver-white and the dorsolateral body was normally coloured (Figure 2 ). The col-

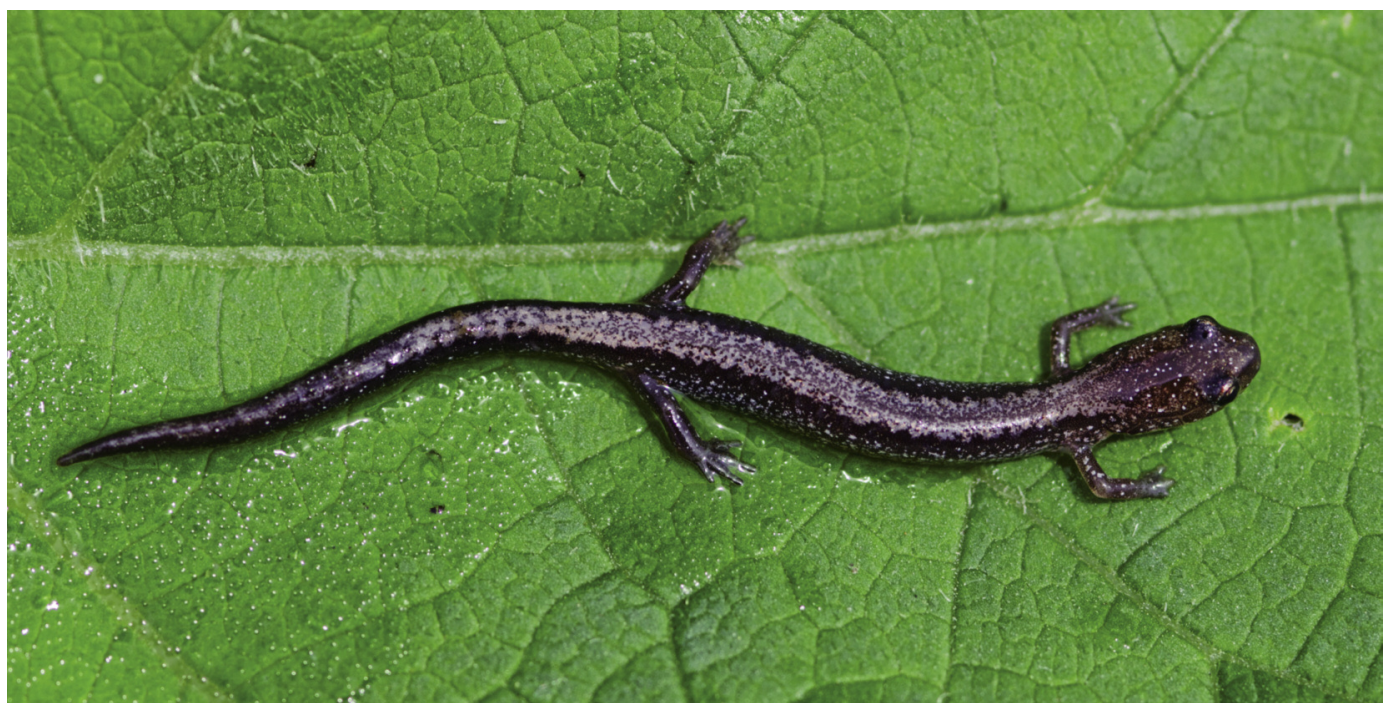

FigURE 1. Silver-white variant of a red-backed morph of the Eastern Red-backed Salamander (Plethodon cinereus) from Québec, Canada. Natural light photo. Photo: M. Ouellet.

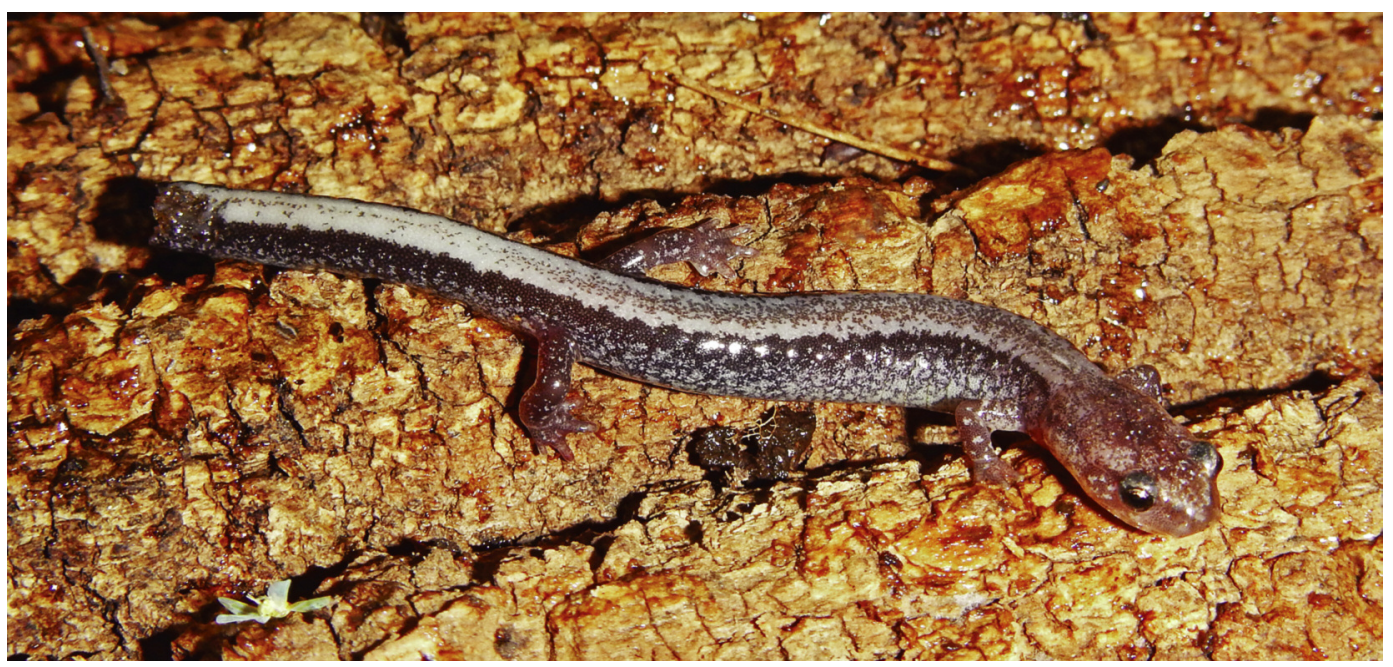

FiguRE 2. Dorsolateral view of a second silver-white variant of the Eastern Red-backed Salamander (Plethodon cinereus) from Québec. Artificial light photo. Photo: J.-D. Moore. 
oration of the ventral body and irises was also typical of the red-backed morph. Snout to vent and total lengths were $37.8 \mathrm{~mm}$ and $73.5 \mathrm{~mm}$, respectively. Autotomy caused tail loss just before photos were taken. A total of 24 other individuals of the red-backed morph of $P$. cinereus were also found in the site during the same survey.

\section{Discussion}

Silver-white variants of the red-backed morph of $P$. cinereus are documented here for the first time in eastern Canada. This phenotype appears to be rare, although it has already been encountered in the United States. In these occurrences, the dorsal stripes vary from gray to silver-white or white. Silver-white variants are thus characterized by the absence of visible xanthophores on the mid-dorsal stripe, compared with other variations of $P$. cinereus, which usually involve yellow and/or red pigment cells (Moore and Ouellet 2014). This phenotype of $P$. cinereus should be distinguished from the cream-backed variant (Figure 4 in Moore and Ouellet 2014) and similar colour combinations ("creamy-white stripe" in Reed 1955). Unlike the silver-white variant, xanthophores (yellow pigment cells in this case) are visible in the dorsal stripe of the creambacked variant. Regarding terminology, the silver-white variants presented here are unrelated to the "axanthic" colour condition reported in certain amphibians, in which all the skin lacks visible xanthophores and iridophores (Lyerla and Dalton 1971; Frost et al. 1984; Jablonski et al. 2014).

Pigmentation plays significant ecological and evolutionary roles for some amphibians, and many amphibian species exhibit phenotypic variation in nature (Frost-Mason et al. 1994; Hoffman and Blouin 2000). Among salamanders, colour polymorphism is particularly common in $P$. cinereus throughout its range. For most of these, the environmental or genetic factors and the mechanisms involved are still unknown. Behavioural differences and the real significance of such coloration is also a matter of debate (Petranka 1998; Gibbs and Karraker 2006; Moore and Ouellet 2015). The role of the dorsal stripe itself in a rather fossorial species like $P$. cinereus is unclear. The red-backed morph may be less fossorial than the lead-backed morph, a hypothesis supported by the presence of fewer costal grooves (vertebrae) in some $P$. cinereus populations (Williams et al. 1968; Fisher-Reid and Wiens 2015). Given also that $P$. cinereus is mostly nocturnal (Piersol 1909; Petranka 1998), visual predation selection pressure at night is likely to be minimal. A wide variety of animals will prey on this salamander, including birds, small mammals, and snakes (Casper 2005; Anthony and Pfingsten 2013). Although colour discrimination by these predators could be limited at night, some studies have suggested that bird and snake predators can nevertheless differentiate coloration in $P$. cinereus, probably when foraging in the leaf litter during the day (Brodie and Brodie 1980; Venesky and Anthony 2007). Both silver-white variants described here appeared in good physical condition among conspecifics of the redbacked morph.

New occurrences of rare or new colour variants in $P$. cinereus are still reported, even though this species has been studied extensively since the 1900s. We hope that this article will prompt documentation of these rare morphs to better assess their prevalence and distribution in North America.

\section{Acknowledgements}

We are grateful to Carl D. Anthony (John Carroll University) for sharing unpublished observations and helpful comments. We also acknowledge Patrick Galois (Amphibia-Nature) and Denise Tousignant (Ministère des Forêts, de la Faune et des Parcs) for reviewing an earlier version of the manuscript.

\section{Literature Cited}

Anthony C. D., and R. A. Pfingsten. 2013. Eastern redbacked salamander, Plethodon cinereus. Pages 335-360 in Amphibians of Ohio: Bulletin of the Ohio Biological Survey (New Series), Volume 17, Number 1. Edited by R. A. Pfingsten, J. G. Davis, T. O. Matson, G. Lipps, Jr., D. Wynn, and B. J. Armitage. Ohio Biological Survey, Columbus, Ohio, USA.

Bishop, S. C. 1941. The salamanders of New York. New York State Museum Bulletin 324: 1-365.

Brodie, E. D., Jr., and E. D. Brodie, III. 1980. Differential avoidance of mimetic salamanders by free-ranging birds. Science 208: 181-182.

Casper, G. S. 2005. Plethodon cinereus (Green, 1818). Pages 796-800 in Amphibian Declines: The Conservation Status of United States Species. Edited by M. Lannoo. University of California Press, Berkeley, California, USA.

Drake, D. L., and K. M. O'Donnell. 2014. Sampling of terrestrial salamanders reveals previously unreported atypical color morphs in the southern red-backed salamander Plethodon serratus. American Midland Naturalist 171: 172-177.

Fisher-Reid, M. C., and J. J. Wiens. 2015. Is geographic variation within species related to macroevolutionary patterns between species? Journal of Evolutionary Biology 28: $1502-1515$.

Frost, S. K., F. Briggs, and G. M. Malacinski. 1984. A color atlas of pigment genes in the Mexican axolotl (Ambystoma mexicanum). Differentiation 26: 182-188.

Frost-Mason, S., R. Morrison, and K. Mason. 1994. Pigmentation. Pages 64-97 in Amphibian Biology, Volume 1: The Integument. Edited by H. Heatwole and G. T. Barthalmus. Surrey Beatty \& Sons, Chipping Norton, New South Wales, Australia.

Gibbs, J. P., and N. E. Karraker. 2006. Effects of warming conditions in eastern North American forests on red-backed salamander morphology. Conservation Biology 20: 913917.

Haines-Eitzen, E. 2015. Plethodon cinereus (Eastern redbacked salamander). Coloration. Herpetological Review 46: 610.

Hickerson, C.-A. M., C. D. Anthony, and B. M. Walton. 2012. Interactions among forest-floor guild members in 
structurally simple microhabitats. American Midland Naturalist 168: $30-42$.

Hoffman, E. A., and M. S. Blouin. 2000. A review of colour and pattern polymorphisms in anurans. Biological Journal of the Linnean Society 70: 633-665.

Jablonski, D., A. Alena, P. Vlček, and D. Jandzik. 2014. Axanthism in amphibians: a review and the first record in the widespread toad of the Bufotes viridis complex (Anura: Bufonidae). Belgian Journal of Zoology 144: 93-101.

Lyerla, T. A., and H. C. Dalton. 1971. Genetic and developmental characteristics of a new color variant, axanthic, in the Mexican axolotl, Ambystoma mexicanum Shaw. Developmental Biology 24: 1-18.

Moore, J.-D., J. Gilhen, and M. Ouellet. 2012. Phénotypes de la salamandre cendrée (Plethodon cinereus) dans le nordest de l'Amérique du Nord. Naturaliste Canadien 136(3): 69-72.

Moore, J.-D., and M. Ouellet. 2014. A review of colour phenotypes of the eastern red-backed salamander, Plethodon cinereus, in North America. Canadian Field-Naturalist 128: $250-259$.

Moore, J.-D., and M. Ouellet. 2015. Questioning the use of an amphibian colour morph as an indicator of climate change. Global Change Biology 21: 566-571.

Neff, M., S. Viernum, S. E. Twitchell, and J. C. Mitchell. 2015. Three more unusually-colored salamanders from North America. Herpetology Notes 8: 599-601.

Petranka, J. W. 1998. Salamanders of the United States and Canada. Smithsonian Institution Press, Washington, DC, USA.
Piersol, W. H. 1909. The habits and larval state of Plethodon cinereus erythronotus. Transactions of the Royal Canadian Institute 8: 469-493.

Reed, C. F. 1955. Notes on salamanders from western Connecticut, with especial reference to Plethodon cinereus. Copeia 1955: 253-254.

Schueler, P. W. 1975. Colour morphs of Plethodon cinereus in New England and New York. Engelhardtia 6: 16-22.

Semlitsch, R. D., K. M. O'Donnell, and F. R. Thompson, III. 2014. Abundance, biomass production, nutrient content, and the possible role of terrestrial salamanders in Missouri Ozark forest ecosystems. Canadian Journal of Zoology 92: 997-1004.

Test, F. H., and B. A. Bingham. 1948. Census of a population of the red-backed salamander (Plethodon cinereus). American Midland Naturalist 39: 362-372.

Venesky, M. D., and C. D. Anthony. 2007. Antipredator adaptations and predator avoidance by two color morphs of the eastern red-backed salamander, Plethodon cinereus. Herpetologica 63: 450-458.

Walton, B. M. 2013. Top-down regulation of litter invertebrates by a terrestrial salamander. Herpetologica 69: 127146.

Williams, E. E., R. Highton, and D. M. Cooper. 1968. Breakdown of polymorphism of the red-backed salamander on Long Island. Evolution 22: 76-86.

Received 16 August 2015

Accepted 21 February 2016 